\title{
PENINGKATAN KEMAMPUAN NUMBER SENSE SISWA MELALUI MEDIA PEMBELAJARAN MATEMATIKA BERBANTUAN SOFTWARE LECTORA INSPIRE
}

\author{
Frida Marta Argareta Simorangkir'1, Ribka Kariani Br Sembiring² \\ ${ }^{1,2}$ Program Studi Pendidikan Matematika Universitas Katolik Santo Thomas \\ ${ }^{1}$ sipudan_86@yahoo.com, ${ }^{2}$ kribka@yahoo.com
}

\begin{abstract}
The objectives of this study were (1) to describe the use of mathematics learning media assisted by the Lectora Inspire software to improve the number sense ability of students, (2) to describe the increase in the ability of students' number sense through mathematics learning media assisted by Lectora Inspire software. The ability of the number sense studied is related to ordinary fractional material. Indicator of the number sense ability in question is understanding the basic meaning of fractions, understanding the effect of operations on fractions and using appropriate calculations. This study is a classroom action research, carried out at SD Swasta Kartika I-2 Medan in the academic year 2018/2019. Based on the results of the study showed that the mathematics learning media assisted by the Lectora Inspire software in the developed class V SD fraction material was declared feasible to use because it could affect the students' number sense ability. Based on the results of the final test in cycle I, there were 15 students $(41.67 \%)$ achieving KKM scores, while the final test results in cycle II obtained 31 students $(86.11 \%)$ achieved the KKM score. Based on the results of the end of cycle I and II tests obtained as many as 16 students (44.44\%) experienced an increase in the number sense ability related to fraction material. The results of the observation sheet for teacher and student activities in the first and second cycles are in good category. Thus it can be stated that there is an increase in the number sense ability of students through mathematics learning media assisted by the Lectora Inspire software.
\end{abstract}

Keywords: Number Sense, Mathematics Learning Media, Lectora Inspire Software

\begin{abstract}
Abstrak. Tujuan penelitian ini adalah (1) mendeskripsikan penggunaan media pembelajaran matematika berbantuan software Lectora Inspire dalam meningkatkan kemampuan number sense siswa, (2) mendeskripsikan peningkatan kemampuan number sense siswa melalui media pembelajaran matematika berbantuan software Lectora Inspire. Kemampuan number sense yang diteliti terkait dengan materi pecahan biasa. Indikator kemampuan number sense yang dimaksud yaitu memahami arti dasar dari pecahan, memahami pengaruh dari operasi pada pecahan dan menggunakan perhitungan yang tepat. Penelitian ini merupakan penelitian tindakan kelas, dilaksanakan di SD Swasta Kartika I-2 Medan tahun pembelajaran 2018/2019. Berdasarkan hasil penelitian menunjukan bahwa media pembelajaran matematika berbantuan software Lectora Inspire pada materi pecahan kelas V SD yang dikembangkan dinyatakan layak digunakan karena dapat mempengaruhi peningkatan kemampuan number sense siswa. Berdasarkan hasil tes akhir pada siklus I diperoleh sebanyak 15 siswa $(41,67 \%)$ mencapai nilai KKM, sedangkan hasil tes akhir pada siklus II diperoleh sebanyak 31 siswa $(86,11 \%)$ mencapai nilai KKM. Berdasarkan hasil tes akhir siklus I dan II diperoleh sebanyak 16 siswa $(44,44 \%)$ mengalami peningkatan kemampuan number sense terkait materi pecahan. Hasil lembar observasi kegiatan guru dan siswa pada siklus I dan II rata-rata dalam kategori baik. Dengan demikian dapat dinyatakan bahwa terjadi peningkatan kemampuan number sense siswa melalui media pembelajaran matematika berbantuan software Lectora Inspire.
\end{abstract}

Kata Kunci: Number Sense, Media Pembelajaran Matematika, Software Lectora Inspire

\section{PENDAHULUAN}

Mata pelajaran matematika perlu diberikan kepada semua peserta didik mulai dari sekolah dasar untuk membekali peserta didik dengan kemampuan berpikir logis, analitis, sistematis, kritis, dan kreatif, serta kemampuan bekerjasama. Kedudukan matematika dalam ilmu pengetahuan adalah sebagai dasar ilmu untuk dapat berkecimpung di dunia 
sains, teknologi ataupun disiplin ilmu lainnya. Mengingat banyak manfaat/kegunaan dalam belajar matematika, diharapkan pembelajaran matematika disesuaikan dengan perkembangan ilmu pengetahuan dan teknologi.

Seiring dengan perkembangan ilmu pengetahuan dan teknologi, proses belajar mengajar hendaknya semakin inovatif dan kreatif dalam pemanfaatan hasil-hasil teknologi. Sebagai fasilitator belajar, guru dituntut agar mampu menggunakan dan dapat mengembangkan keterampilan membuat media pembelajaran dengan memanfaatkan hasilhasil teknologi. Media merupakan alat bantu pembelajaran yang dapat bertindak sebagai penyalur informasi secara langsung ataupun tidak langsung dalam proses pembelajaran. Dengan kata lain digunakannya media pembelajaran dalam proses belajar mengajar akan berpengaruh pada siswa. Dengan demikian, siswa akan lebih mudah memahami materi pelajaran dari pada tanpa bantuan media. Pemanfaatan media pembelajaran yang sesuai dapat menumbuhkan minat belajar, bahkan meningkatkan hasil belajar siswa (Daryanto, 2013).

Demikian pula dalam pembelajaran matematika, diperlukan media pembelajaran yang tepat agar dapat meningkatkan keingintahuan dan minat belajar siswa. Salah satu materi yang dianggap sulit dan tidak diminati di tingkat sekolah dasar adalah pecahan. Berdasarkan hasil observasi dan wawancara dengan siswa di SD Swasta Kartika I-2 Medan mengenai manakah yang lebih besar nilainya $\frac{1}{3}$ atau $\frac{1}{4}$ ? Salah satu siswa menjawab $\frac{1}{4}$ karena penyebutnya bernilai 4. Siswa yang lain menjawab $\frac{1}{3}$, namun tidak mengemukakan alasan jawaban. Kesalahan siswa dalam menjawab soal tersebut berkaitan dengan pemahaman siswa terhadap bilangan.

Pemahaman bilangan yang dimaksud adalah number sense. Number sense merupakan suatu pemahaman yang apabila dilatih dan dikembangkan dengan benar akan bermanfaat bagi siswa karena sangat baik untuk mendukung kecerdasan logika dalam bidang matematika terutama bilangan. Dengan demikian dapat dinyatakan bahwa kemampuan number sense mengacu pada suatu pembelajaran yang mendorong siswa memahami dunia konseptual bilangan yang mencakup kemampuan mereka untuk mengukur ketepatan jawaban dan memecahkan masalah dengan cara yang bermanfaat dan memadai (Tonra, 2016).

Oleh karena itu dibutuhkan media pembelajaran yang tepat untuk dapat membantu siswa memahami materi pelajaran khususnya pecahan. Salah satu contoh media pembelajaran yang baik untuk digunakan adalah Lectora Inspire. Lectora Inspire dapat digunakan untuk kebutuhan pembelajaran baik secara online maupun offline yang dapat dibuat dengan cepat dan mudah. Salah satu kelebihan Lectora Inspire adalah terdapat software lain sebagai pendukung sehingga dapat digunakan untuk mengembangkan media pembelajaran yang interaktif dan membuat simulasi yang menarik. Dalam Lectora Inspire dapat dikreasikan gambar dan animasi yang menarik terkait materi pecahan sehingga siswa termotivasi dalam belajar.

Hasil penelitian oleh Zuhri \& Rizaleni (2016) bahwa Lectora inspire merupakan software pengembangan belajar elektronik (e-learning) yang relatif mudah diaplikasikan atau diterapkan karena tidak memerlukan pemahaman bahasa pemrograman yang canggih. Media Lectora Inspire mempunyai potensi besar untuk meningkatkan motivasi belajar peserta didik dibandingkan pembelajaran konvensional. Selain itu, dengan menggunakan Lectora Inspire penelitian memperoleh hasil bahwa media terbukti valid, praktis dan efektif meningkatkan hasil belajar peserta didik.

Berdasarkan hasil penelitian tersebut disimpulkan bahwa melalui Lectora Inspire, pesan atau informasi berupa pengetahuan, keahlian, kemampuan, ide, pengalaman dan 
sebagainya dapat disampaikan dengan baik kepada siswa. Selain bermanfaat bagi siswa, penggunaan media pembelajaran matematika berbantuan software Lectora Inspire dapat membantu guru dalam menyampaikan materi pecahan dengan baik sehingga dapat meningkatkan kemampuan number sense siswa.

\section{METODE}

Penelitian ini merupakan Penelitian Tindakan Kelas (Classroom Action Research). Tindakan/rancangan siklus dalam penelitian ini menggunakan model Kemmis dan McTaggart dimulai dari perencanaan (planning), tindakan (acting), pengamatan (observing), dan refleksi (replanning) sebagai dasar untuk pemecahan masalah.

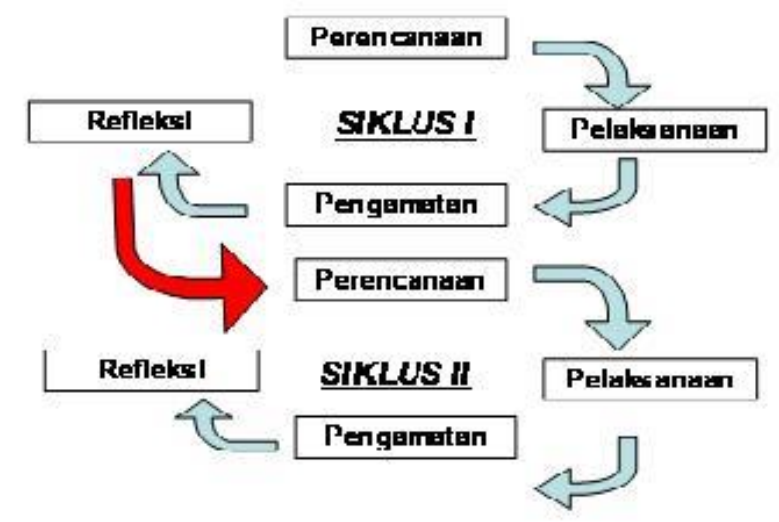

Gambar 1. Penelitian Tindakan Kelas menggunakan model Kemmis dan McTaggart

Penelitian dilaksanakan di SD Swasta Kartika I-2 Medan tahun pembelajaran 2018/2019. Subjek penelitian ini adalah siswa kelas V yang berjumlah 36 orang siswa. Sedangkan objek dalam penelitian ini adalah peningkatan kemampuan number sense siswa melalui media pembelajaran matematika berbantuan software Lectora Inspire. Data dalam penelitian ini terbagi dua yaitu data tes (nilai tes kemampuan number sense siswa) dan data non tes (hasil dari observasi guru dan siswa di kelas). Tes dilakukan di setiap akhir siklus atau tindakan ke-2 dari setiap siklus. Soal yang diberikan berupa 5 soal uraian. Penilaian terhadap kemampuan number sense berpedoman pada kisi-kisi instrumen tes yang telah dibuat. Tes yang dilakukan pada akhir siklus memuat materi pecahan. Pengumpulan data non tes dilakukan dengan cara : (1) melalui observasi langsung dengan menggunakan lembar observasi kegiatan pembelajaran guru dan siswa. Observasi langsung dilaksanakan sejak awal kegiatan pembelajaran sampai berakhirnya kegiatan pembelajaran, (2) catatan lapangan untuk mencatat setiap tindakan/aktivitas guru maupun siswa, baik yang positif maupun negatif, serta hal apa saja yang mempengaruhi pelaksanaan tindakan dalam pembelajaran di kelas, (3) dokumentasi berupa foto-foto selama kegiatan pembelajaran berlangsung, dan (4) wawancara dengan siswa dan observer.

Analisis data pada penelitian ini yaitu analisis data kualitatif dan kuantitatif. Data kualitatif didapatkan dari pengisian lembar pengamatan, catatan lapangan, catatan hasil observasi di lapangan, dan catatan hasil wawancara siswa. Analisis data kualitatif pada penelitian ini dilakukan dengan cara menggabungkan data kualitatif agar dapat diambil kesimpulan sejauh mana media pembelajaran matematika berbantuan software Lectora Inspire mempengaruhi peningkatan kemampuan number sense siswa. Analisis data kuantitatif dilakukan dengan menganalisa data kuantitatif secara deskriptif seperti menghitung jumlah siswa yang tuntas dan belum tuntas, menghitung presentase nilai, serta menghitung skor pengamatan aktivitas guru dan siswa. 


\section{HASIL DAN PEMBAHASAN}

Penelitian ini berhasil karena terjadi peningkatan kemampuan number sense siswa terkait materi pecahan melalui penggunaan software Lectora Inspire. Indikator terjadinya peningkatan kemampuan number sense siswa tentang mengurutkan pecahan yaitu siswa mampu membuat acuan nilai, siswa mampu melakukan estimasi dan siswa memahami manakah nilai pecahan yang lebih kecil, lebih besar atau nilainya sama. Indikator terjadinya peningkatan kemampuan number sense siswa dalam operasi penjumlahan, pengurangan, perkalian dan pembagian pecahan yaitu siswa mampu menyusun bilangan secara alami, siswa mampu membuat acuan, siswa mampu mengoperasikan besarnya bilangan yang relatif dan mutlak, serta menggunakan hubungan diantara operasi hitung dalam pecahan.

Sebelum pelaksanaan penelitian, dilakukan observasi awal terhadap kemampuan number sense siswa pada materi pecahan. Dari observasi dan wawancara diperoleh informasi bahwa siswa masih kurang berkembang kemampuan number sense-nya. Hal ini dapat diketahui dari siswa yang bisa menjawab pertanyaan guru dengan jawaban yang tepat apabila diberi soal berupa angka-angka tetapi pada waktu diberikan variasi soal, siswa mengalami kesulitan dalam mengerjakannya dan juga mengalami kesulitan dalam mengkomunikasikan alasan mereka memilih cara tertentu untuk menyelesaikan soal. Oleh karena itu, diperlukan media pembelajaran sebagai alat bantu yang tepat untuk meningkatkan kemampuan number sense siswa. Hal ini menjadi dasar untuk penggunaan media pembelajaran matematika berbantuan software Lectora Inspire.

Penelitian ini dilakukan sebanyak 2 siklus dengan 2 kali tindakan setiap siklusnya. Pada siklus I tindakan 1 dan 2 yang dilakukan adalah menggunakan gambar sebagai media dengan software Lectora Inspire. Gambar-gambar yang disajikan pada tindakan 1 menujukkan manakah pecahan yang nilainya lebih besar, lebih kecil atau sama. Gambargambar yang disajikan pada tindakan 2 menunjukkan urutan pecahan.

Pada pelaksanaan tindakan siklus I, dilakukan evaluasi hasil belajar pada akhir siklus guna melihat sejauh mana peningkatan kemampuan number sense siswa dalam mengurutkan pecahan. Evaluasi dilakukan dengan memberikan 5 soal uraian. Berdasarkan hasil evaluasi didapatkan nilai rata-rata kelas 50 dan hanya ada 15 siswa (41,67\%) yang nilainya lebih atau sama dengan KKM yaitu 70. Hal ini disebabkan oleh jawaban siswa belum tepat terhadap soal tes yang diberikan. Penyebab yang lain adalah kesalahan siswa dalam menentukan kelipatan persekutuan terkecil (KPK) dari beberapa bilangan, dimana konsep KPK merupakan salah satu materi prasyarat untuk mempelajari pecahan. Selain itu, siswa juga mengalami kesulitan membandingkan manakah nilai pembilang atau penyebut yang terbesar, apabila nilai pembilang atau penyebut tidak disamakan.

Meskipun nilai rata-rata secara klasikal rendah, tetapi ditinjau dari persentase siswa yang nilainya lebih atau sama dengan KKM yaitu $41,67 \%$ dinyatakan bahwa siswa menguasai aspek keteraturan dalam pecahan, mengelompokkan pecahan, membuat sistem acuan/patokan, menyimpulkan dan mampu mengurutkan pecahan. Hal ini menunjukkan bahwa pada dasarnya siswa sudah memiliki beberapa aspek number sense yang berkembang. Perubahan perilaku siswa yang terjadi akibat pembelajaran yang terpantau pada siklus ini yaitu siswa mampu membedakan manakah pecahan yang nilainya lebih kecil, lebih besar atau sama berdasarkan gambar yang ditunjukkan dengan software Lectora Inspire.

Sebanyak 21 siswa $(58,33 \%)$ mendapat nilai lebih rendah dari KKM. Hal ini menunjukkan bahwa siswa masih perlu berlatih agar aspek number sense dapat berkembang dalam pola berpikirnya. Selain itu, berdasarkan hasil lembar observasi diperoleh hasil observasi kegiatan guru yaitu kegiatan inti sebesar 4,20 (kategori baik), pendahuluan sebesar 4,15 (kategori baik), penutup sebesar 3,25 (kategori cukup), dan pengelolaan waktu sebesar 3,20 (kategori cukup). Sedangkan hasil observasi kegiatan 
siswa yaitu kegiatan inti sebesar 4,05 (kategori baik), pendahuluan sebesar 3,57 (kategori cukup), penutup sebesar 3,41 (kategori cukup), dan pengelolaan waktu sebesar 3,55 (kategori cukup). Berdasarkan nilai akhir siklus I dan hasil lembar observasi kegiatan guru serta siswa dapat dinyatakan bahwa penggunaan gambar-gambar tersebut dinilai masih kurang efektif dalam mempengaruhi peningkatan kemampuan number sense siswa. Oleh karena itu, penelitian dilanjutkan pada siklus berikutnya.

Penggunaan animasi dan video dengan software Lectora Inspire dilakukan pada siklus II. Penggunaan animasi dan video tersebut menunjukkan operasi penjumlahan, pengurangan, perkalian dan pembagian pecahan. Pelaksanaan tindakan 1 dan 2 pada siklus II menunjukkan perbedaan yang cukup signifikan dari siklus I. Hal ini dapat ditinjau dari catatan kekurangan pada lembar observasi kegiatan guru dan siswa serta meningkatnya kemampuan number sense siswa. Pada pelaksanaan tindakan siklus II, dilakukan evaluasi hasil belajar pada akhir siklus guna melihat sejauh mana peningkatan kemampuan number sense siswa dalam operasi penjumlahan, pengurangan, perkalian dan pembagian pecahan. Evaluasi dilakukan dengan memberikan 5 soal uraian terkait materi pecahan.

Berdasarkan hasil evaluasi didapatkan nilai rata-rata kelas 73 dan 31 siswa $(86,11 \%)$ nilainya lebih atau sama dengan KKM yaitu 70, artinya hampir seluruh siswa dari 36 siswa telah meningkat kemampuan number sense-nya. Hal ini disebabkan oleh hal berikut : (1) siswa memahami bagaimana menentukan kelipatan persekutuan terkecil (KPK) dari beberapa bilangan, (2) mampu menjumlahkan dan mengurangkan pembilang dengan pembilang, penyebut dengan penyebut, (3) mampu mengubah pecahan beda penyebut menjadi pecahan yang berpenyebut sama kemudian melakukan perkalian atau pembagian untuk pembilangnya, (4) mampu mengubah pecahan beda penyebut menjadi pecahan yang berpenyebut sama kemudian melakukan penjumlahan atau pengurangan.

Selain itu, berdasarkan hasil lembar observasi diperoleh hasil observasi kegiatan guru yaitu kegiatan inti sebesar 4,25 (kategori baik), pendahuluan sebesar 4,10 (kategori baik), penutup sebesar 4,05 (kategori baik), dan pengelolaan waktu sebesar 4,23 (kategori baik). Sedangkan hasil observasi kegiatan siswa yaitu kegiatan inti sebesar 4,20 (kategori baik), pendahuluan sebesar 4,17 (kategori baik), penutup sebesar 4,15 (kategori baik), dan pengelolaan waktu sebesar 4,25 (kategori baik).

Berdasarkan hasil tes akhir siklus I dan II diperoleh sebanyak 16 siswa $(44,44 \%)$ mengalami peningkatan kemampuan number sense terkait materi pecahan. Terjadinya peningkatan kemampuan number sense siswa juga dipengaruhi oleh media pembelajaran dengan software Lectora Inspire. Media pembelajaran tersebut memberikan keleluasaan bagi siswa untuk menciptakan suasana yang menyenangkan sehingga siswa termotivasi untuk belajar. Siswa dengan semangat mengikuti pembelajaran sehingga tidak menganggap matematika sebagai pelajaran yang membosankan. Terciptanya suasana menyenangkan dapat mendorong siswa untuk menciptakan cara kreatif dalam belajar. Cara kreatif yang demikian menyebabkan kemampuan number sense siswa berkembang.

Oleh karena itu, dapat dinyatakan bahwa penggunaan animasi dan video dengan software Lectora Inspire pada siklus ini efektif. Hal ini juga didukung berdasarkan hasil lembar observasi kegiatan guru dan siswa dalam kategori baik serta ketuntasan klasikal yang sudah tercapai. Oleh karena itu penelitian tidak lagi dilanjutkan pada siklus berikutnya. Berdasarkan hasil penelitian pembahasan yang telah dijelaskan sebelumnya, dapat disimpulkan bahwa media pembelajaran dengan software Lectora Inspire dapat meningkatkan kemampuan number sense siswa dalam materi pecahan. 


\section{KESIMPULAN}

Dari hasil penelitian diperoleh kesimpulan sebagai berikut:

1. Kemampuan number sense siswa dapat meningkat pada setiap siklus dalam penelitian tindakan, hal ini bergantung pada media pembelajaran yang diberikan.

2. Media pembelajaran matematika berbantuan software Lectora Inspire memotivasi siswa untuk belajar dan membantu siswa belajar. Hal ini karena melalui media tersebut, pembelajaran tidak membosankan.

3. Media pembelajaran matematika berbantuan software Lectora Inspire yang digunakan membantu siswa untuk mengembangkan pemahaman terkait materi pecahan.

4. Media pembelajaran matematika berbantuan software Lectora Inspire memberikan kesempatan bagi siswa untuk mengkomunikasikan gagasan, ide dan pemahaman dalam menyelesaikan masalah terkait materi pecahan.

5. Media pembelajaran matematika berbantuan software Lectora Inspire dapat meningkatkan kemampuan number sense dalam materi pecahan.

\section{Saran}

Adapun saran berdasarkan hasil penelitian yang dapat dijadikan bahan pertimbangan adalah:

1. Lectora Inspire perlu diterapkan oleh guru agar pembelajaran menarik dan inovatif.

2. Lectora Inspire perlu dikembangkan pada pokok bahasan yang lain agar dapat mengembangkan berbagai aktivitas dan kreativitas siswa dalam pembelajaran.

3. Perlu adanya penelitian lebih lanjut dengan menerapkan pada pokok bahasan yang berbeda.

\section{UCAPAN TERIMAKASIH}

Pada kesempatan ini peneliti mengucapkan terima kasih kepada Universitas Katolik Santo Thomas yang telah memberikan dukungan dalam kegiatan penelitian, LPPM Universitas Katolik Santo Thomas sebagai fasilitator dan memberikan motivasi dalam melaksanakan penelitian serta Kemenristek DIKTI (DP2M DIKTI) yang telah membiayai penelitian ini.

\section{DAFTAR PUSTAKA}

Daryanto. (2013). Media Pembelajaran. Yogyakarta: Gava Media

Febrianto, Arif. 2013. Pemanfaatan Lectora Inspire Sebagai Media Pembelajaran Fiqih Siswa Kelas X MAN Maguwoharjo Sleman Yogyakarta. Skripsi. S1. Fakultas Tarbiyah Dan Keguruan. UIN Sunan Kalijaga Yogyakarta

Rahmawati., Annisa., Isroah. 2013. Penggunaan Media Lectora Inspire X.6 untuk Meningkatkan Hasil Belajar Akuntansi Siswa SMK Ma'arif 1. Jurnal Pendidikan Akuntansi Indonesia, XI(2), h. 91-98.

Rochmad. 2012. Desain Model Pengembangan Perangkat Pembelajaran Matematika. Jurnal Kreano, 3(1).

Romadhan, Akbar dan Puput Wanarti Rusimamto. 2015. Pengembangan Media Pembelajaran Menggunakan Multimedia Interaktif Lectora Inspire Pada Mata Pelajaran Teknik Elektronika Dasar Di SMK Negeri 3 Jombang. Jurnal Pendidikan Teknik Elektro, 04(02), h. 451-456.

Sugiyono. 2010. Metode Penelitian Kualitatif Kunatitatif dan $R \& D$. Bandung: Alfabeta.

Sukamto, S., Wardani, A. 2016. Pembelajaran Matematika Menggunakan CD Interaktif AMT Berbasis Lectora Inspire untuk Siswa SD. Mimbar Sekolah Dasar, 3(1). 19-28 (http://dx.doi.org/10.17509/mimbar-sd-v3i1.2353) 
Frida Marta Argareta Simorangkir, Ribka Kariani Br Sembiring Peningkatan Kemampuan Number Sense Siswa Melalui Media Pembelajaran...

Tonra, W.S. 2016. Pembelajaran Number Sense untuk Meningkatkan Hasil Belajar Siswa Sekolah Dasar pada Materi Pecahan. Jurnal Matematika dan Pendidikan Matematika, 5(2), h. 109-116.

Zuhri, M.S., Rizaleni, E.A. 2016. Pengembangan Media Lectora Inspire dengan Pendekatan Kontekstual pada Siswa SMA Kelas X. PYTHAGORAS, 5(2), h. 113119. 